\title{
Modeling of heat transfer around a square and a circle: A novel ANN-based approach
}

\author{
Kare ve yuvarlak silindir etrafundaki ısı transferinin modellenmesi: Yeni YSA \\ temelli bir yaklaşım
}

\author{
Özge Yetik ${ }^{1, *}$ \\ ${ }^{1}$ Eskisehir Osmangazi University, Mechanical Engineering Department,26480, Eskisehir, Turkey
}

\begin{abstract}
Artificial neural network (ANN) is a modelling of the human brain. The aim of this study is to estimate the heat distribution with ANN around different cylinders. Within the scope of the study, square and circular cylinders were discussed. In this study, the temperature analysis of the cylinders was carried out with a program written in Fortran, not using a package program whose exact background is unknown. The results obtained from a writing code are more reliable. The study is discussed in two dimensions. The 3 most commonly used algorithms (Levenberg Marguardt (LM), Pola-Ribiere Conjugate Gradient (CGP) and Scaled Conjugate Gradient (SCG)) were used to train with ANN. Cylinder type, $\mathrm{x}$-coordinate and y-coordinate were the input variables; and temperature was the output variable. The most suitable algorithm was found to be LM18 algorithm. The proximity of artificial neural networks and real values was evaluated statistically. These were $\mathrm{R}^{2}$, $\mathrm{CoV}$ and RMSE. $\mathrm{R}^{2}, \mathrm{CoV}$ and RMSE values in the training phase of Levenberg - Marguardt -18 neuron were determined to be $0.9939,0.0044,0.0107$ while their values in the test phase were 0.9850, 0.0043 and 0.0190 respectively. The fact that the $R^{2}$ value is so close to 1 is an indication that ANN is working very well.
\end{abstract}

Keywords: Levenberg-Marquardt, Heat transfer, Numerical simulation, Artificial neural network

\section{Introduction}

Heat transfer around the cylinders forms the basis of many engineering problems including, for example, heat exchangers, heat losses of high-rise buildings, turbines, chimneys and pipes. Unwanted heat losses can trigger structural failure and cause undesirable situations. Therefore, heat losses around the cylinders are the main problems of engineering. Franke et al. [1] numerically monitored the flow around the square and round cylinders between the numbers Reynolds 5000 and 300 . The study was carried out by using two-dimensional, finite volume method and Quadratic upwind difference scheme (QUICK) method together. They compared their studies to previous experimental studies, and they reported that, for $\mathrm{Re}$ cases less than 1000, the dependence of the number $\operatorname{Re}$ on the Strouhal and drag coefficient provided accurate results. It was observed that
Özet

Yapay sinir ağları (ANN) insan beyninin bir modellemesidir. Bu çalışmanın amacı da ANN ile farklı silindirler etrafindaki 1sı dağılımını tahmin etmektir. Çalışma kapsamında kare ve daire silindirler ele alınmıştır. Bu çalışmada, silindirlerin sıcaklık analizi, tam arka planda ne yaptığ 1 bilinmeyen bir paket program kullanılmadan, fortran dili kullanılarak gerçekleştirilmiştir. Kod yazarak elde edilen sonuçlar daha güvenilir sonuçlardır. Çalışma iki boyutlu olarak ele alınmıştır. ANN ile verilerin eğitilmesinde en yaygın kullanılan 3 farklı algoritma (Levenberg-Marguardt (LM), Pola-Ribiere Conjugate Gradient (CGP) ve Scaled Conjugate Gradient (SCG)) kullanılmıştır. Silindir tipi, x-koordinatı ve y koordinatı girdi verileri, sıcaklık ise çıktı verisidir. En uygun algoritma LM-18 algoritması olarak bulunmuştur. Yapay sinir ağları ile gerçek değerlerin birbirine yakınlığ ${ }_{1}$ istatistiksel olarak değerlendirilmistir. Bunlar $\mathrm{R}^{2}$, CoV ve RMSE'dir. LM-18 algritmasının eğitim aşamasındaki $\mathrm{R}^{2}$, CoV ve RMSE değerleri sirasiyla 0.9939, 0.0044, 0.0107; test aşamasındaki değerleri sırasıyla 0.9850, 0.0043, 0.0190'dir. $\mathrm{R}^{2}$ değerinin 1 'e bu kadar yakın olması ANN'nin çok iyi çalıştığının da göstergesidir.

Anahtar kelimeler: Levenberg-Marquardt, Is1 transferi, Sayısal benzetim, Yapay sinir ağları

there were deviations in larger Re numbers, and the reason was said to be due to fluctuations. Sharma and Eswaran [2] studied the flow and heat transfer around a single square cylinder. They discussed their work under laminar flow. They took the Reynolds number between 1 and 160, and the Prandtl number was 0.7. The heat transfer on the cylinder was examined for uniform heat flux and constant cylinder temperature conditions. The relationship between Nusselt and Reynolds was studied. Sohankar et al. [3] studied the flow and heat transfer around a square cylinder under laminar flow. They used Semi-Implicit Method for Pressure Linked Equations-Consistent (SIMPLEC), Quadratic upwind difference scheme and Crank - Nicolson method in their studies. Sommerfeld conditions and Neumann conditions were compared. Traditional conditions were shown to yield more effective results. The study was

\footnotetext{
* Sorumlu yazar / Corresponding author, e-posta / e-mail: oyetik@ ogu.edu.tr (Ö. Yetik)

Geliș / Recieved: 20.07.2020 Kabul / Accepted: 22.04.2021 Yayımlanma / Published: 27.07.2021

doi: $10.28948 /$ ngmuh.771650
} 
conducted by using Stuart-Landau equations. Strouhal number, drag, lift and moment coefficients were calculated. Chatterjee et al. [4] took the Re number 150 and placed 5 identical cylinders side by side to examine the heat transfer in the cylinders. Cylinders have identical temperatures. Calculations were made using the finite volume method based on the PISO algorithm. The effect of the space was examined by changing the space between the cylinders between 0.2 and 10. Average and instantaneous drag and lift coefficient, average Nusselt number and Strouhal numbers were determined and interpreted. Malavasi and Guadagnini [5] examined the flow around a single rectangular cylinder in a flow open to the atmosphere. They carried out experiments by placing cylinders at different heights from the bottom of the channel and using different flow conditions. Bai et al. [6] studied the interaction between a single cylinder placed near the free surface and the surface empirically and numerically. The experiments were carried out in a water channel with cylinders of variable axial depth. Scardovelli and Zaleski [7] studied the flow around the cylinder numerically. They stated that the method they used was very simple and that the results could not be obtained correctly for three-dimensional studies. As a result, it was stated that it was difficult to obtain the linear theory for some flows due to simulation and cut-off current instabilities. Liu et al. [8] used Fluent to examine the flow in two dimensions in their studies. They modelled the flow by the k-turbulence model and the free surface by the volume of fluid method Arslan and Yetik [9] made the estimation and optimization of the data of power cycles such as ORC-Binary. They used the Levenberge Marguardt (LM), Pola-Ribiere Conjugate Gradient (CGP), Scaled Conjugate Gradient (SCG) and Gradient descent with momentum and adaptive learning rate back propagation (GDX) algorithms from artificial neural networks. Levenberg - Marguardt -16 neuron algorithm for s1 type cycle and Levenberg - Marguardt -14 neuron algorithm for s2 type cycle were found to be the most appropriate algorithm. Arslan and Yetik [10] used ANN to estimate the electricity production from the binary cycle, which is a kind of organic rankine cycle. Conducting these studies is a complex work that requires time and more competence. Levenberg - Marguardt -20 neuron was the best algorithm for o2 and o3 type cycles while Levenberg Marguardt -22 neuron algorithm was the best algorithm for b3 type cycles. Sochinskii et al. [11] examined numerically the heat transfer and hydrodynamics around the diamond type cylinder. Reynolds number was between 1 and 70 whereas Pr number was taken as 0.7. The results were compared with a circle cylinder. Dash and Dash [12] examined the flow and heat transfer around the hollow cylinder. By changing the length ratio of the cylinder diameter, the change in the Nusselt number was examined. A correlation was obtained for the cooling curve and Nusselt number. Hina et al. [13] examined mathematically the flow and heat transfer around the cylinder. Equations related to the Cross model were used in the mathematical formulation. Numerical calculations were made with Matlab. They said that their work was compatible with the literature. An important outcome of this study is that increased strength leads to a reduction in resistant wall cutting and helps axial flow significantly. ANN has been used in various fields such as internal combustion engines applications, thermal power plants, solar thermal power plant, thermal stratification of solar storage, the temperature of internal combustion engines, the performance of geothermal systems, waste heat in High-Velocity Oxygen Fuel coating process [14-19]. Robichaux et al. and Shimizu and Tanida [20, 21]. studied 2D and 3-D flow constructures. Sohankar and Etminan [22] studied numerical simulation on the flow attribute and heat transfer over isothermal tandem square cylinders.

In packet programs, not knowing the steps behind the program exactly increases insecurity. The differences that distinguish this study from the studies in the literature are that the program used is written in a problem-specific way using Fortran language and predictions are made with ANN. There are scientific and technological benefits of working in the design of pipelines placed in seas and oceans, the design of structures to be built in seas, the design of power generating equipment using tidal events, and electronic equipment development. The heat transfers over a cylinder were previously solved by different package programs. At the same time, in this study, the aim is to obtain an ANN modelling of heat transfer over a cylinder. This paper presents the results of a numerical study on the heat transfer over a square and a circle cylinder. Also the numerical data were carried out by the Fortran code. No such study has been conducted previously with ANN. Previously, there was no study examining the heat transfer around the cylinder and only writing a special code for this problem, and also this study did not estimate it with ANN. Therefore, it will make an important contribution to the literature.

\section{Problem statement and analysis}

\subsection{Numerical solution}

The energy equation is solved with a finite volume method in two dimensional geometries. The 2-D NavierStokes and the dimensionless form of the governing energy equations is given as [23]:

$$
\begin{gathered}
\frac{\partial u}{\partial x}+\frac{\partial v}{\partial y}=0 \\
\frac{\partial u}{\partial t}+u \frac{\partial u}{\partial x}+v \frac{\partial u}{\partial y}=-\frac{\partial p}{\partial x}+\frac{1}{R e}\left(\frac{\partial^{2} u}{\partial x^{2}}+\frac{\partial^{2} u}{\partial y^{2}}\right) \\
\frac{\partial v}{\partial t}+u \frac{\partial v}{\partial x}+v \frac{\partial v}{\partial y}=-\frac{\partial p}{\partial y}+\frac{1}{R e}\left(\frac{\partial^{2} v}{\partial x^{2}}+\frac{\partial^{2} v}{\partial y^{2}}\right) \\
\frac{\partial T}{\partial t}+u \frac{\partial T}{\partial x}+v \frac{\partial T}{\partial y}=\frac{1}{R e P r}+\left(\frac{\partial^{2} T}{\partial x^{2}}+\frac{\partial^{2} T}{\partial y^{2}}\right)
\end{gathered}
$$

$\mathrm{u}$ and $\mathrm{v}$ are the dimensionless velocity components, $\mathrm{T}$ and $\mathrm{p}$ is the dimensionless temperature and pressure, respectively. $\mathrm{t}$ represents the dimensionless time. Prandtl number is defined as $\operatorname{Pr}=v / \alpha$, where $v$ is kinematic viscosity and $\alpha$ is 
thermal diffusivity. Re is defined with respect to cylinder length D. Nondimensional form of the variables defined as

$$
\begin{gathered}
u=\frac{u^{*}}{U} \\
v=\frac{v^{*}}{U} \\
p=\frac{p^{*}}{\rho U^{2}} \\
t=\frac{t^{*} U}{D} \\
x=\frac{x^{*}}{D} \\
y=\frac{y^{*}}{U}
\end{gathered}
$$

where $U$ is the average velocity.

Industrial aspects of the problem: it is like electronic device design, power equipment design and natural gas pipe design. The configuration of the square and circle cylinders are illustrated in Figure 1 and Figure 2. The boundary conditions can be stated as:

For the inlet, $\mathrm{T}=10^{\circ} \mathrm{C}$

For the outlet, $\mathrm{T}=10^{\circ} \mathrm{C}$

For the top, $\mathrm{T}=10^{\circ} \mathrm{C}$

For the bottom, $\mathrm{T}=10^{\circ} \mathrm{C}$

For the cylinders walls, $\mathrm{T}=50^{\circ} \mathrm{C}$

In order to prevent the flow around the cylinders from being affected by the walls, the distance to the walls was taken 10 times the cylinder dimensions. All of the data should be normalized in order to estimate the values correctly in artificial neural networks. Both square and circle cylinders were chosen as a simplified form of structures such as pipes and power teams in the sea.

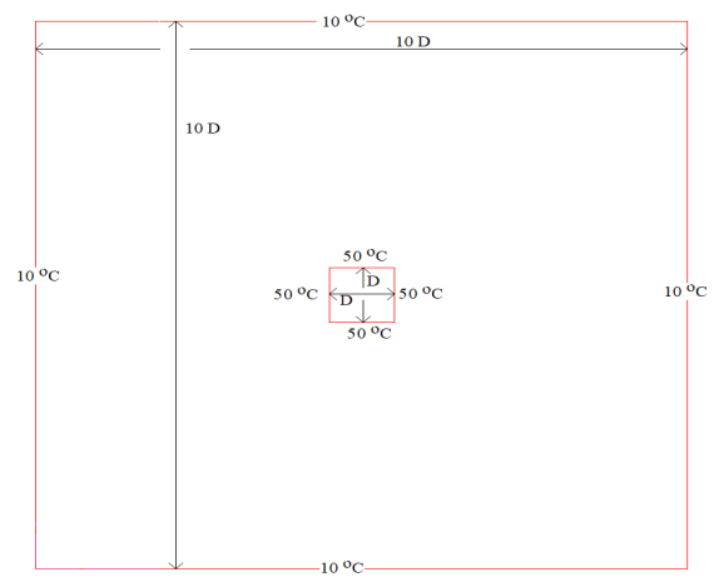

Figure 1. Square cylinder configuration

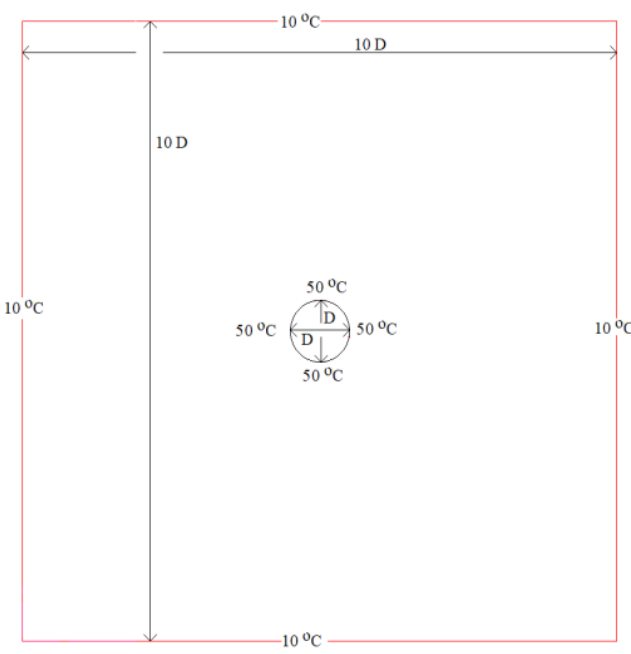

Figure 2. Circle cylinder configuration

Equations were solved using a staggered grid. The Equation (11) was used in order to observe the independent behaviour of the temperature on flow area. $n$ is the time step. $T_{i, j}$ is the temperature value in each mesh element. Heat transfer in the $2 \mathrm{D}$ regime were performed with a cell-centred finite volume code based and staggered grid were used.

$$
\sqrt{\frac{\sum\left(T_{i, j}^{n}-T_{i, j}^{n-1}\right)^{2}}{\sum\left(T_{i, j}^{n}\right)^{2}}} \leq 10^{-4}
$$

The computational area is meshed using non-orthogonal quadrilateral elements (10D $x$ 10D). When the mesh structure is not uniform, both the number of equations increase and equations become more complicated. The trustworthiness control of the mesh number was investigated. While the worth of mesh arised from 1207 to 4786, the distinction in the temperature was $0.9 \%$. The mesh number was 3071 for the ideal value which provided accurate results while keeping computational run time shorter. Figure 3 and Figure 4 showed that mesh structure.

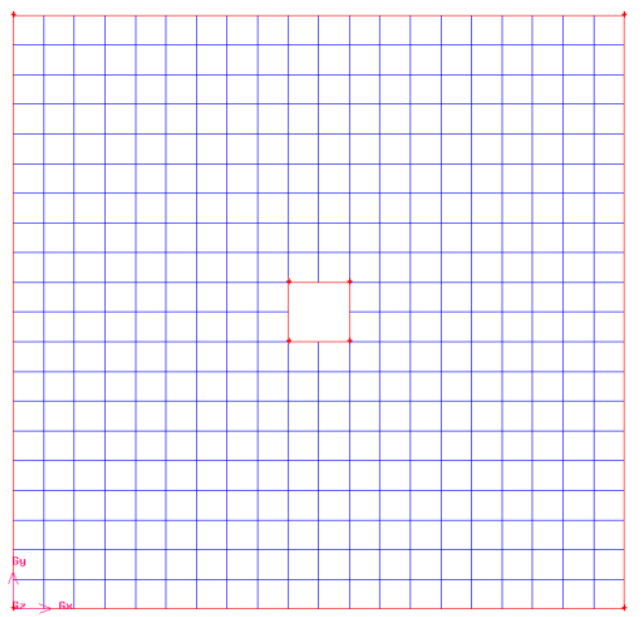

Figure 3. Mesh structure for square cylinder 


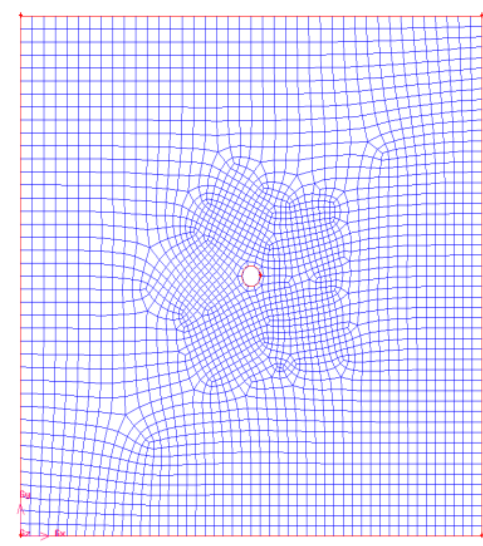

Figure 4. Mesh structure for circle cylinder

\subsection{ANN modelling of heat transfer}

Artificial neural networks are based on computers learning data. ANN is commonly used to estimate an output from input values. Artificial neural networks collect information about samples, make generalizations, and then make decisions about those samples using the information they acquire compared with the samples they have never seen. Due to these learning and generalization features, artificial neural networks have wide application possibilities in many science fields and demonstrate the ability to successfully solve complex problems. ANN can be used to predict problems that take a long time to result. The advantages of artificial neural networks are its non-linear structure, its ability to be designed with input and output matching, its ability to adapt, and its fault tolerance. Many algorithms may be preferred when solving problems with ANN, but the most commonly used and best results algorithms are Levenberg-Marguardt (LM), Pola-Ribiere Conjugate Gradient (CGP), Scaled Conjugate Gradient (SCG) and Gradient descent with momentum and adaptive learning rate back propagation (GDX). It is seen in the literature that the LM algorithm gives the fastest and best results $[9,10,24]$.

To use the data in ANN, the data must be normalized to the range of $[0,1]$ and the normalization method is given by Equation (12). The logarithmic sigmoid (logsig) transfer function was defined Equation (12) [25].

$$
y^{\prime}=\frac{y_{i}-y_{\min }}{y_{\max }-y_{\min }}
$$

$y^{\prime}$ is normalized data, $y_{i}$ is input value, $y_{\min }$ is the smallest number in the input set, $y_{\max }$ is the largest number in the input set.

$$
f(z e)=\frac{1}{1+e^{-z e}}
$$

ze is the weighted sum. Equation (14) is given in ze. w is weight, $\mathrm{y}$ is output and $\mathrm{b}$ is bias.

$$
z e_{j}=\sum_{i=1}^{n} w_{i j} y_{i}+b_{j}
$$

The data obtained were evaluated with some statistical methods. Equation is given between (15) and (17). $y_{\text {output }}$ is the output value, $\bar{y}_{\text {output }}$ is the average of the output, $y_{\text {real }}$ is the actual value, $\bar{y}_{\text {real }}$ is the average of the actual value and $n$ is the pattern number in the calculations as follows:

$$
\begin{gathered}
R^{2}= \\
\frac{\sum_{m=1}^{n}\left(y_{\text {output }}-\bar{y}_{\text {output }}\right)\left(y_{\text {real }}-\bar{y}_{\text {real }}\right)}{\sqrt{\sum_{m=1}^{n}\left(y_{\text {output }}-\bar{y}_{\text {output }}\right)^{2}} \sum_{m=1}^{n}\left(y_{\text {real }}-\bar{y}_{\text {real }}\right)^{2}} \\
R M S E=\sqrt{\frac{\sum_{n=1}^{n}\left(\frac{\left.y_{\text {output }}-\bar{y}_{\text {real }}\right)^{2}}{y_{\text {output }}}\right.}{n}} \\
\operatorname{CoV}=\frac{\sum_{m=1}^{n}\left(y_{\text {output }}-\bar{y}_{\text {output }}\right)\left(y_{\text {real }}-\bar{y}_{\text {real }}\right)}{n}
\end{gathered}
$$

Parameters affecting the power of statistical analysis such as $R^{2}, R M S E, \mathrm{CoV}$ are the pattern number and the effect size. Effect size is the measure of the strength of the statistical relationship between two variables (output and real). Solution steps with flow chart are given in Figure 5.

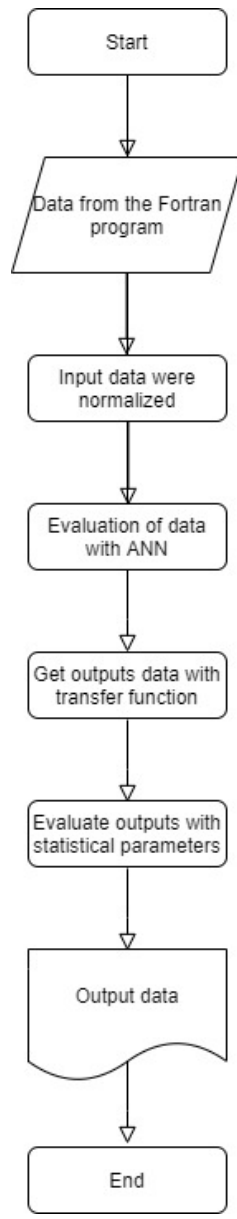

Figure 5. Solution steps with flow chart 


\section{Results and discussion}

In this study, the heat distribution around the square and circle cylinders was studied with the Fortran code that was written by the author. The mesh in the flow area was selected smoothly and complexly. Cylinders were selected to be 50 ${ }^{0} \mathrm{C}$ and walls in the flow area were selected to be $10{ }^{\circ} \mathrm{C}$. The temperature distribution of a cylinder warmer than the walls was investigated. It is important that we work for the design of pipelines placed in the seas and oceans, the design of structures to be built in the seas, the design of power generating equipment using tidal events, and the design of electronic equipment. Figures 6 to 8 show the temperature distributions of computational area. We see that as the temperature around the cylinder approaches $500 \mathrm{C}$, the temperature decreases approaching edges. Figure 8 shows the 3D temperature distribution. Tanweer et al. [26] studied heat transfer around a single square cylinder. Khanafer and Vafai [27] studied heat transfer around a single circular cylinder. In both studies, it was shown that flows spread around the cylinders in waves, and the package program was used in both studies. Tanweer et al. used OpenFOAM and Khanafer and Vafai used Adina v.9.2.

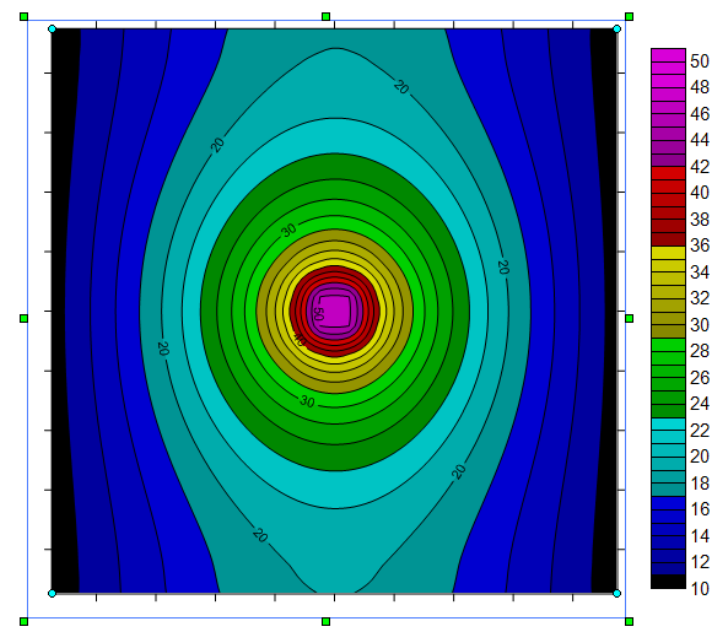

Figure 6. Temperature distribution for square cylinder

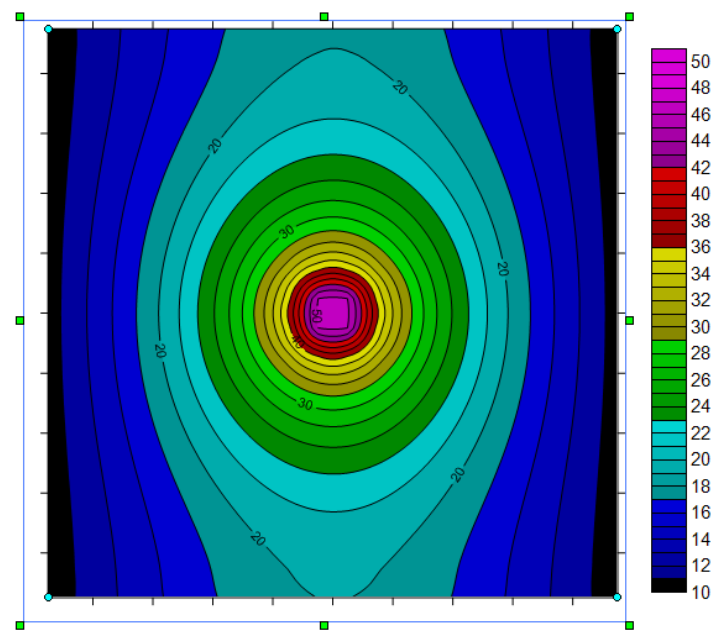

Figure 7. Temperature distribution for circle cylinder

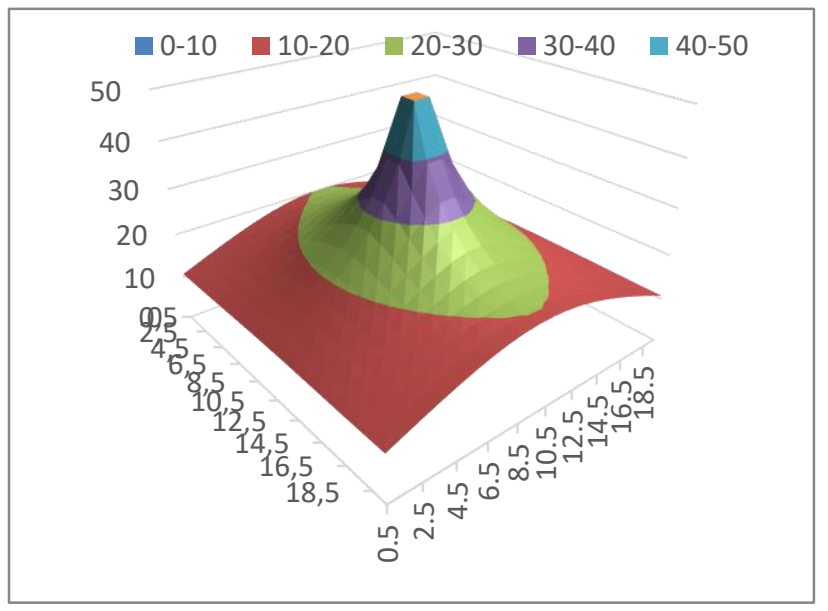

Figure 8. 3D Temperature distribution for square cylinder

When the cylinder was hot and the walls of the environment housing the cylinder were colder; it could be seen that the temperature spread in waves around the cylinder. Even if the shape of the cylinder was square or round, the temperature distribution was similar. At the same time, the independence of the result from the mesh was tested using different mesh structures.

Writing code takes a long time and requires more competence. Therefore, the results are estimated with ANN. The number of inputs for ANN modelling of heat transfer around the square and circle cylinder is 3: cylinder type, $\mathrm{x}$ coordinate, $y$-coordinate. Temperature was obtained as the output. The total number of data used is $3071.80 \%$ (2456) of them were used for training and $20 \%$ (613) for testing. The ANN was trained for 1000 iterations in a single hidden layer. The data to be used for testing and training were randomly selected. It was attempted to find the most suitable algorithm by increasing the number of neurons of the LM algorithm. Statistical formulas were used in this study. The best-found LM algorithm were compared with CGP and SCG algorithms. The summarized results according to the statistical performance evaluation are given in Table 1 and Table 2.

Looking at Table 1 and Table 2, the reliable estimates of the temperature of the cylinders are given with ANN. LM 18 was found to be the best ANN algorithm with its representation given in Figure 9. The comparison of the data obtained as a result of ANN with the actual data is given in Figure 10.

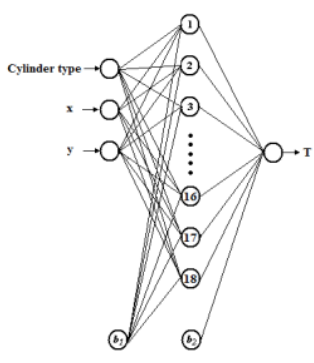

Figure 9. Architecture of the best ANN Topology 
Table 1. Comparison of error values of LM Algorithms in the ANN

\begin{tabular}{lccccccccc}
\hline \multirow{2}{*}{ Algorithm } & \multicolumn{3}{c}{ Train } & \multicolumn{3}{c}{ Test } & \multicolumn{2}{c}{ All } \\
\cline { 2 - 9 } & CoV & $\boldsymbol{R M S E}$ & $\boldsymbol{R}^{2}$ & CoV & $\boldsymbol{R M S E}$ & $\boldsymbol{R}^{\mathbf{2}}$ & CoV & $\boldsymbol{R} \boldsymbol{M S E}$ & $\boldsymbol{R}^{\mathbf{2}}$ \\
\hline LM 6 & 0.0042 & 0.0351 & 0.9410 & 0.0041 & 0.0375 & 0.9381 & 0.0042 & 0.0356 & 0.9404 \\
LM 8 & 0.0042 & 0.0263 & 0.9645 & 0.0041 & 0.0280 & 0.9633 & 0.0042 & 0.0267 & 0.9642 \\
LM 10 & 0.0043 & 0.0254 & 0.9692 & 0.0042 & 0.0285 & 0.9664 & 0.0042 & 0.0261 & 0.9687 \\
LM 12 & 0.0043 & 0.0186 & 0.9823 & 0.0043 & 0.0228 & 0.9772 & 0.0043 & 0.0196 & 0.9813 \\
LM 14 & 0.0044 & 0.0169 & 0.9853 & 0.0043 & 0.0222 & 0.9789 & 0.0043 & 0.0181 & 0.9840 \\
LM 16 & 0.0044 & 0.0157 & 0.9880 & 0.0043 & 0.0218 & 0.9797 & 0.0044 & 0.0170 & 0.9864 \\
LM 18 & 0.0044 & 0.0107 & 0.9939 & 0.0043 & 0.0190 & 0.9850 & 0.0044 & 0.0128 & 0.9922 \\
LM 20 & 0.0044 & 0.0136 & 0.9914 & 0.0043 & 0.0217 & 0.9814 & 0.0044 & 0.0156 & 0.9894 \\
LM 22 & 0.0044 & 0.0140 & 0.9904 & 0.0043 & 0.0205 & 0.9819 & 0.0044 & 0.0155 & 0.9887 \\
LM 24 & 0.0043 & 0.0200 & 0.9805 & 0.0042 & 0.0238 & 0.9748 & 0.0043 & 0.0208 & 0.9793 \\
\hline
\end{tabular}

Table 2. Comparison of error values of LM, SCG and CGP algorithms in the ANN

\begin{tabular}{lccccccccc}
\hline \multirow{2}{*}{ Algorithm } & \multicolumn{3}{c}{ Train } & \multicolumn{3}{c}{ Test } & \multicolumn{3}{c}{ All } \\
\cline { 2 - 11 } & CoV & $\boldsymbol{R M S E}$ & $\boldsymbol{R}^{\mathbf{2}}$ & $\mathbf{C o V}$ & $\boldsymbol{R M S E}$ & $\boldsymbol{R}^{\mathbf{2}}$ & $\mathbf{C o V}$ & $\boldsymbol{R M S E}$ & $\boldsymbol{R}^{\mathbf{2}}$ \\
\hline CGP 18 & 0.0043 & 0.0224 & 0.9742 & 0.0042 & 0.0245 & 0.9720 & 0.0043 & 0.0228 & 0.9737 \\
LM 18 & 0.0044 & 0.0107 & 0.9939 & 0.0043 & 0.0190 & 0.9850 & 0.0044 & 0.0128 & 0.9922 \\
SCG 18 & 0.0043 & 0.0208 & 0.9771 & 0.0042 & 0.0240 & 0.9736 & 0.0043 & 0.0215 & 0.9764 \\
\hline
\end{tabular}

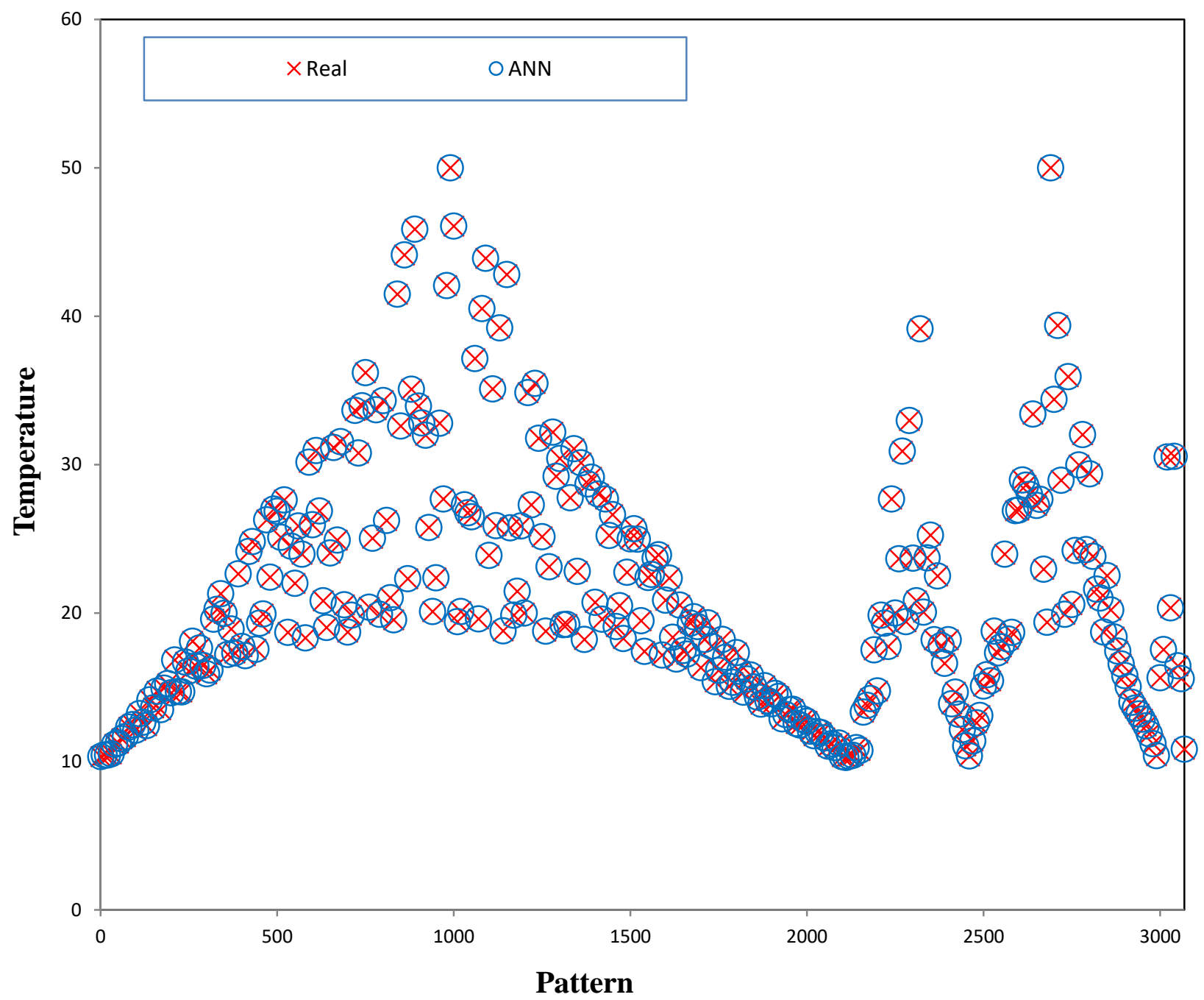

Figure 10. The comparison of ANN prediction and analytic design results 


\section{Results and discussion}

The heat transfer around the cylinders is the basis of the engineering problems. It is not reliable because we do not know exactly what the program does in solving heat transfer with packaged programs. For this reason, the code was encoded with Fortran coding language to model the heat transfer around the cylinder. The data obtained requires a long time and more competence. ANN was used to estimate the results of this study. In this study, heat transfer over a square and circle cylinder was modelled. In the study, the walls of the cylinder $50{ }^{\circ} \mathrm{C}$, flow area were taken at $10^{\circ} \mathrm{C}$. The most common ANN algorithms including LM, CGP and SCG were used. The best result was obtained with LM 18. The R2 value of the LM 18 algorithm in the test step was 0.9850 , the CoV value was 0.0043 and the RMSE value was 0.0190 . The R2 value of the LM 18 algorithm in the training step was 0.9939 , the CoV value was 0.0044 and the RMSE value was 0.0107 .

\section{Conflict of interest}

The authors declare that there is no conflict of interest.

\section{Similarity Index (iThenticate): 14\%}

\section{References}

[1] R. Franke, W. Rodi and B. Schönung, Numerical calculation of laminar vortex-shedding flow past cylinders. Journal of Wind Engineering and Industrial Aerodynamics, 35, 237-257, 1990. https://doi.org/ 10.1016/ 0167-6105(90)90219-3.

[2] A. Sharma and V. Eswaran, Heat and fluid flow across a square cylinder in the two-dimensional laminar flow regime. Numerical Heat Transfer, Part A, 45, 247-269, 2004. https://doi.org/10.1080/10407780490278562.

[3] A. Sohankar, C. Norberg and L. Davidson, Lowreynolds number flow around a square cylinder at incidence: study of blockage, onset of vortex shedding and outlet boundary condition. International Journal for Numerical in Fluids, 26, 39-56, 1998. https://doi.org/10.1002/(SICI)10970363(19980115)26: $1<39::$ AID-FLD623>3.0.CO;2-P.

[4] D. Chatterjee, G. Biswas and S. Amiroudine, Numerical investigation of forced convection heat transfer in unsteady flow past a row of square cylinders. International Journal of Heat and Fluid Flow, 30, 11141128, 2009. https://doi.org/10.1016/j.ijheatfluidflow. 2009.09.004

[5] S. Malavasi and A. Guadagnini, Interactions between a rectangular cylinder and a freesurface flow. Journal of Fluids and Structures, 23, 1137-1148, 2007. https://doi.org/10.1016/j.jfluidstructs.2007.04.002.

[6] J. Bai, N. Ma and X. Gu, Study of interaction between wave-current and the horizontal cylinder located near the free surface. Applied Ocean Research, 67, 44-58, 2017. https://doi.org/10.1016/j.apor.2017.06.004.

[7] R. Scardovelli and S. Zaleski, Direct numerical simulation of free-surface and interfacial flow. Annual Review of Fluid Mechanics, 31, 567-603, 1999. https://doi.org/10.1146/annurev.fluid.31.1.567.
[8] I-H. Liu, J. Riglin, WC. Schleicher and A. Oztekin, Flow past a plate in the vicinity of a free surface. Ocean Engineering, 111, 323-334, 2016. https://doi.org/ 10.1016/j.oceaneng.2015.11.009.

[9] O. Arslan and O. Yetik, ANN based optimization of supercritical ORC-binary geothermal power plant: Simav case study. Applied Thermal Engineering, 31, 3922-3928, 2011. https://doi.org/10.1016/ j.applthermaleng. 2011.07.041.

[10] O. Arslan and O. Yetik. ANN modeling of an ORCBinary geothermal power plant: Simav case study. Energy Sources, Part A: Recovery, Utilization and Environmental Effects, 36, 418-428, 2014. https://doi.org/10.1080/15567036.2010.542437.

[11] A. Sochinskii, D. Colombet, M. Muñoz, F. Ayela and N. Luchier, Flow and heat transfer around a diamondshaped cylinder at moderate Reynolds number. International Journal of Heat and Mass Transfer, 142, 118435, 2019. https://doi.org/10.1016/ j.ijheatmasstransfer.2019.118435.

[12] M. K. Dash and S. K. Dash, Natural convection heat transfer and fluid flow around a thick hollow vertical cylinder suspended in air: a numerical approach. International Journal of Thermal Sciences, 152, 106312, 2020. https://doi.org/10.1016/ j.ijthermalsci.2020.106312.

[13] S. Hina, A. Shafique and M. Mustafa, Numerical simulations of heat transfer around a circular cylinder immersed in a shear-thinning fluid obeying cross model. Physica A, 540, 123184, 2020. https://doi.org/10.1016/j.physa.2019.123184.

[14] P. Géczy-Víg and I. Farkas, Influence of the time step in ANN modelling of thermal stratification of solar storage. Proceedings of the 17 th World Congress, pp. 9575-9578, Seoul, Korea, 6-11 July 2008.

[15] K. Goudarzi, A. Moosaei and M. Gharaati, Applying artificial neural networks (ANN) to the estimation of thermal contact conductance in the exhaust valve of internal combustion engine. Applied Thermal Engineering, 87, 688-697, 2015. https://doi.org/ 10.1016/j.applthermaleng.2015.05.060.

[16] T.E. Boukelia, O. Arslan and M.S. Mecibah, Potential Assessment of a parabolic trough solar thermal power plant considering hourly analysis: ANN-based approach. Renewable Energy, 105, 324-333, 2017. https://doi.org/10.1016/j.renene.2016.12.081.

[17] M. Esfe, S. Esfandeh, M. Afrand, M. Rejvani and S. Rostamian, Experimental evaluation, new correlation proposing and ANN modeling of thermal properties of EG based hybrid nanofluid containing znodwent nanoparticles for internal combustion engines applications. Applied Thermal Engineering, 133, 452463, 2018. https://doi.org/10.1016/ j.applthermaleng. 2017.11.131.

[18] R. Shankar, K.R. Balasubramanian, S.P. Sivapirakasam and K. Ravikumar, ANN and RSM models approach for optimization of HVOF coating. Materials Today: 
Proceedings, (Article in press) 2020. https://doi.org/10.1016/j.matpr.2020.01.211.

[19] J. Wanga, Y. Zhaia, P. Yaoa, M. Maa and H. Wang, Established prediction models of thermal conductivity of hybrid nanofluids based on artificial neural network (ANN) models in waste heat system. International Communications in Heat and Mass Transfer, 110, 104444, 2020. https://doi.org/10.1016/ j.icheatmasstransfer.2019.104444.

[20] J. Robichaux, S. Balachandar and S.P. Vanka, Threedimensional Floquet instability of the wake of square cylinder. Physics of Fluids, 11, 560-578, 1999. https://doi.org/10.1063/1.869930.

[21] Y. Shimizu and Y. Tanida, Fluid forces acting on cylinders of rectangular cross section. Transc JSME B, 44, 2699-2706, 1978.

[22] A. Sohankar and A. Etminan, Forced-convection heat transfer from tandem square cylinders in cross flow at low Reynolds numbers. International Journal for Numerical Methods in Fluids, 60, 733-751, 2009. https://doi.org/10.1002/fld.1909.

[23] D. Chatterjee and B. Mondal, Forced convection heat transfer from tandem square cylinders for various spacing ratios. Numerical Heat Transfer Part A:
Applications, $\quad 61, \quad 381-400, \quad 2012$. https://doi.org/10.1080/10407782.2012.647985.

[24] X. Qian, D. Xuan, X. Zhao and Z. Shi, Heat dissipation optimization of lithium-ion battery pack based on neural networks. Applied Thermal Engineering, 162, 114289, 2019. https://doi.org/10.1016/ j.applthermaleng.2019.114289.

[25] A. Yüksek, H. Bircan, M. Zontul ve O. Kaynar, Sivas ilinde yapay sinir ağları ile hava kalitesi modelinin oluşturulması üzerine bir uygulama. Cumhuriyet Üniversitesi İktisadi ve İdari Bilimler Dergisi, 8, 97112, 2007.

[26] S. Tanweer, A. Dewan and S. Sanghi, Influence of gapratio on flow dynamics and heat transfer for a square cylinder approaching a moving wall in turbulent regime. International Journal of Heat and Mass Transfer, 172, 121122, 2021. https://doi.org/ 10.1016/j.ijheatmasstransfer.2021.121122.

[27] K. Khanafer and K. Vafai, Effect of a circular cylinder and flexible wall on natural convective heat transfer characteristics in a cavity filled with a porous medium. Applied Thermal Engineering, 181, 115989, 2020. https://doi.org/10.1016/j.applthermaleng.2020.115989. 